\title{
Strategies to Create Competitive Advantage Through Promotions at Samana Resto Villa and Catering
}

\section{Gusti Made Oka Astana ${ }^{*}$}

${ }^{1}$ Sekolah Tinggi Ilmu Ekonomi Satya Dharma, Indonesia

\section{ART I CLE INFO}

Article history:

Received March 26, 202

Revised April 03, 2021

Accepted May 01, 2021

Available online May 25, 2021

Keywords:

VRIO, Promotions,

Competitive Advantage

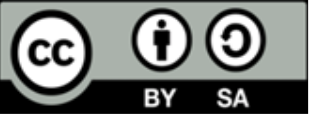

This is an open access article under the CC BY-SA license.

Copyright $(2021$ by Author. Published by Universitas Pendidikan Ganesha.

\begin{abstract}
A B S T R A C T
This study aims to create excellence compete at the Samana Resto Villa and Catering. Data collection techniques used in. This study uses documentation techniques and interview techniques with several informants. The results of this study explain that based on the results of the VRIO analysis obtained from interviews with several informants, it was found that there were 18 resource and capability that can be specified are 8 tangible resource competencies and resources There are 6 intangibles while for the capabilities there are 4 . Competencies owned Samana Resto Villa and Catering more from a resource aspect than capabilities because resource competencies are 14 and there are 4 competencies. Based on 18 resources and capability included in the highly rated category need a new strategy such as for the resources there are strategies that can be done, namely from Human resources, by involving human resources in workshops, seminars or training regarding the Resto Villa and Catering industry as well as increasing the number of competent employees in the hospitality industry; Facility strategy can be done with maximize the use of the internet as a means of promoting the dissemination of information as well as a branding tool; Location, to draw visitors are not only a strategic location but also need cooperation with travel parties and tour agents, because this strategy can be done as a means promotions and branding; The use of technology can have done by leveraging android to increase promotion and increase services with android applications. While the strategy that can be done from the side Capabilities; Service Skills with care improve employee abilities in serving visitors and improving language skills by following training; networking skills, this can be done by increasing the number network and cooperation so as to create new networks and can improve number of visitors.
\end{abstract}

\section{INTRODUCTION}

The tourism industry today showing outward developments regular so that is one great contributor to national income (Asty, 2017; Mucharreira et al., 2019). Bali is one area that is very famous for its tourist objects. Tourist attraction in Bali with cultural uniqueness is a great potential for the development of the tourism sector in Bali. This condition is proven with an increase in the number of visits foreign tourists who come to the Province Bali. Based on data from the Central Agency Statistics of Bali Province, an increase foreign tourist visits in Bali from year after year, namely 2015 to with 2019. Increasing numbers tourist visits in 2016 an increase of 14.89\% from the previous year. In 2017 and 2019 the increase is still happening is below $10 \%$, namely $2017 \mathrm{an}$ increase of $6.24 \%$ and in $2019 \mathrm{an}$ increase of $3.37 \%$. Increased visits the greatest tourists happen in 2018 which reached 51.69\% of the previous year. Increase in tourist visits in the province of Bali had an impact on increase in visitors to that Resto Villa and Catering is in Bali. The concerns companies have are either how to fit innovativeness into their business or the lack of skills to encourage and foster innovativeness in order to achieve sustainable competitive advantage (Appiahene et al., 2019; Song, 2012).

The number of new Resto Villa and Catering sprung up to cause competition tight between Resto Villa and Catering increasingly complex. Party the Resto Villa and Catering must be able to apply the concept marketing accordingly and right with the demands of the current era so that it remains glimpsed Resto Villa and Catering service users. Renewal for renewal as well must be done by the management Resto Villa and Catering so as not to be left behind with the Resto Villa and Catering other. This condition too faced by the existing Resto Villa and Catering business. Successful ventures perform a combination of 
business activities well, including marketing, production, distribution, finance, customer service, and/or other activities important to the enterprise. However, a competitive advantage is often a single key element that gives an edge to a business beyond what the competition has or does (Appiahene et al., 2019; Masri \& Jaaron, 2017). North Bali namely Buleleng especially Resto Villa and Catering non-starred from 20016-2019 dominant has increased. On 2017 the number of non-star Resto Villa and Catering an increase of $47.69 \%$ and year2018 did not change and on 2019 has increased $11.46 \%$ from the previous year. Increased number of non-star Resto Villa and Catering Buleleng Regency. An increasing number of Resto Villa and Catering are occurs resulting in the movement of the Resto Villa and Catering business getting narrower considering the number new competitors that emerged. Wrong one non-star Resto Villa and Catering that in Baturiti Regency is Samana Resto Villa and Catering, precisely in front of the Baturiti area. The number of villas and other Resto Villa and Catering that are starting to appear is a big challenge for Samana Resto Villa and Catering. This condition who demands the Samana Resto Villa and Catering to be able to dig and develop sources of competitive advantage in order can survive. The source of excellence competing can be found from resource owned by the business. Competitive advantage is factors by which a company can get more superior to its competitors in a competitive environment (Lenggogeni \& Ferdinand, 2016).

All other factors unchanged, the greater the competitive advantages of the investing firms, relative to those of other firms, the more they are likely to be able to engage in or increase, their foreign production (Djokoto, 2021). Competitive advantage interpreted as a benefit strategy companies that do cooperation to create a competitive advantage more effective in its market. Strategy it must be designed to make it happen competitive advantage continuously so that the company can dominate both in the market and new markets (Butarbutar et al., 2017). Basically competitive advantage grow from its values or benefit created by the company for the customers (Shidqi \& Tricahyono, 2017). The company needs to implement integrated information system to obtain information that is relatively fast, precise and accurate for decision-making, with the hope of influencing the way of working, improving the smooth flow of information in the pattern level business value chain, and eventually the company may have competitive advantage compared with company that still apply the system manually (Alianto \& Arlan, 2012).

Winning the competition and just build a competitive advantage not enough to make a thing enduring but key effort its success is building sustainable competitive advantage (Haryanto et al., 2019). The conceptual KKB (excellence Sustainable Competitive) is at his company is said to have an edge competitive sustainable when he was undertake a value creation strategy not simultaneously run by existing or potential competitors other and current companies others are unable to duplicate the advantages of this strategy (Ahmad, 2013). Competitive advantage assessment the sustainability of an enterprise can be assessed with the VRIO framework to see differences by resource (source power) it has. VRIO is short for valuable, rare, imitate to cost, and organized. VRIO can used to view comparisons comparative strength and weakness in the company's internal conditions. Competitive advantage assessment sustainable with VRIO really important so is the case with Samana Resto Villa and Catering needs to rate and create a competitive advantage sustainable to stay afloat with today's competition. This study aims to create excellence compete at the Samana Resto Villa and Catering.

\section{METHODS}

This study uses data quantitative and qualitative. The data source in research, namely secondary data sources and Primary data sources. Collection technique data in research that is using documentation techniques and techniques Interview (Sugiyono, 2011). This research is qualitative in nature by using descriptive analysis that is, the analysis was carried out after data collected through interviews and direct observation in the field. According (Umar, 2002) data analysis consisted of intermediate stages others: Data collection is an activity collection of existing data first; Data reduction is defined as a process selection, focus on simplification, abstracting and data transformation arising from records field. In other words, reduction data is part of that analysis sharpen, classify, redirect, discard those that don't necessary, and organize data; Display data, in this stage various data that has been collected and considered importance is further illustrated in description form to make it easier see the whole picture so that it can help formulate right conclusion; Conclusion drawing or verification the last stage of data analysis is draw a conclusion. Withdrawal this conclusion depends on the magnitude collection of notes in the field, storage, prowess, and foresight at in analyzing the rough data. The data analysis in the study these are: Conduct interviews with informants namely visitors stay at Samana Resto Villa and Catering, Resto Villa and Catering Manager and Marketing Managers, the surrounding community as well one of Samana Resto Villa and Catering is in the Baturiti area; Summarize the results of the interview into the VRIO analysis 
table VRIO is structured with a number inquiries about business activities company, which is about values (value), rarity (rarity), imitability (possibility of imitation), and organization. All answers will determine whether are sources or capabilities owned by the company is a strength or weakness.

\section{RESULTS AND DISCUSSIONS}

\section{Results}

Capital turnover ratio comparison work Based on the results of interviews with some of the informants above can is shown the VRIO Samana analysis Resto Villa and Catering is studied from the aspect of resources and the capabilities. Based above, can be explained the results of the VRIO analysis in Samana Resto Villa and Catering, there is a grouping about resources and capabilities owned. Tangible resource competence which is owned by Samana Resto Villa and Catering namely The extent of the breadth of the place, the location of the Resto Villa and Catering, the quality of human resources, Resto Villa and Catering Facilities, Resto Villa and Catering Design, Quality Rooms, Use of technology and Capital, while resource competency intangibles owned by Samana Resto Villa and Catering, namely collaboration with online travel agent (OTA), collaboration with offline travel agent, cooperation with services accommodation, cooperation with the object tourism that is around, Relationship with the surrounding environment/community, and Relations with Visitors. Besides resource competence and competence capabilities of Samana Resto Villa and Catering, namely marketing skills, service skills, Resto Villa and Catering building and design skills, and Networking skills.

VRIO analysis at Samana Resto Villa and Catering mentioned above can be explained that there are alternative strategies to maximize resources and Capability owned by Samana Resto Villa and Catering. Alternative strategy specifically referred to in resources and capability which is still in that category competitive parity and temporary competitive advantage in order to be sustained competitive advantage. Based on the results VRIO analysis as for the strategies included in the competitive parity category, namely: Quality of human resources, Resto Villa and Catering facilities and capital. Strategies that fall into the category temporary competitive at Samana Resto Villa and Catering namely: Resto Villa and Catering location, usage technology, Service Skills, Networking abilities/skills. On the other hand, for those who are already in the category sustained competitive advantage, resource and capability does not require strategy special or new strategy, but strategy this is required to be able to continue to maintain as well continue to do maintenance on existing strategy.

Based on the results of the level analysis interest in resource and capability at Samana Resto Villa and Catering there are several resource and capability required will be new strategies for development business, which consists of 2 (two) competitive parity, namely (1) Quality of human resources (Human Resources) and (2) Facilities Resto Villa and Catering (Wi-Fi), where 2 (two) of temporary competitive advantage of competence resources, namely (1) Location and (2) Use of technology and temporary competitive advantage of competence capabilities, namely (1) Service Skills, and (2) Networking abilities/skills, then there are 8 (eight) of the sustained competitive advantage in the field of resources, namely, (1) Resto Villa and Catering design, (2) Room Quality, (3)Collaboration with online travel agents (OTA), (4) Collaboration with offline travel agent, (5) Cooperation with accommodation services, (6) Cooperation with the tourist attraction around (7) Relationship with environment/surrounding community and (8) Relations with Visitors meanwhile sustained competitive advantage in this field capability, namely Ability/Skill marketing, Ability/Skill building and designing Resto Villa and Catering.

\section{Discussion}

Based explanation as above there are alternative strategy formulations are made to increase resource usage and capability at Samana Resto Villa and Catering to be able to maximize its business. These alternative strategies were chosen are the strategies already considered and has been selected by the parties Samana Resto Villa and Catering as a strategy that allows fordone, here is the explanation: Strategy efforts that can done for HR strategy done by including HR in the event workshop, seminar or training regarding the hospitality industry as well additional number of employees have competence in the industrial field hospitality, it is also possible to done because according to the head of the Resto Villa and Catering as the owner of the Samana Resto Villa and Catering he has prepared this far the day before and will be soon realize for an increase in the number employees and participation in seminars in the near future. Next is related with Resto Villa and Catering facilities, namely the use of Wi-Fi which can be used to maximize use of the internet, namely as a means promotion of dissemination of information regarding Samana Resto Villa and Catering as well as branding tool, the strategy allows it to be done because Samana Resto Villa and Catering already has the tools and the resources needed, parties Samana Resto Villa and Catering is just a must maximize use of access the internet is owned to be a means promotion and 
branding. So the Wi-Fi facilities are there are not just additions facilities for Resto Villa and Catering visitors and employees however can be used as promotion media.

Next to the strategy with travel parties and tour agents, this strategy is carried out as a means of promotion and branding for Samana Resto Villa and Catering, this is possible considering the Resto Villa and Catering leadership has been separated budgeting funds from the results Samana Resto Villa and Catering income. Strategy use of technology in marketing indeed this time is very needed and must maximized by following the current trend this is good promotion on social media, web etc. In addition, the use of technology can use to improve services by means of all activities both ordering food, drinks, tour packages or other activities can be used with android application, this is also done for make it easy for visitors so as to create comfort and satisfaction so visitors will grow a sense for a return visit. In general, the added value of a service is generated in the direct interaction of the provider system with the contributions of the customer. Therefore, the treatment processes that create value directly represent the most important lever to achieve competitive advantages (Töpfer \& Brabänder, 2021). The personalisation of treatment processes-ideally in the form of treatment pathways - thus forms the linchpin for the strategy, organisation and implementation, and for the effectiveness of treatment programmes and sequences. Company or brand image is significant because it ultimately provides the company a competitive advantage for their business (Barone et al., 2007).

Talking about capabilities, namely These service skills can be honed or maximized by giving service training and also training an increase in the quality of English because it is the basics of business concern. Because not all fields fit in English so expected can improve language skills by attending trainings. The rationale behind this question is the fact that the mere presence of any resource alone cannot lead to competitive advantage. As for networking skills, this is not it easy things require skill extraordinary in order to be able to create a new network. Expect an increase in the number of networks or cooperation with many parties will spur Resto Villa and Catering is widely known so visitors are increasing. The positive experience of successful companies in Asia, US and Europe assures that advanced production system can help to gain and sustain competitive advantages. This good interaction benefits the receivers in learning new knowledge, and they are becoming the new knowledge disseminators in the end, which promotes the generation of new knowledge and exerting a promotional effect (Blake \& Kerr, 2019). An increase in the number of visitors for sure expectations that all Resto Villa and Catering desire including the Samana Resto Villa and Catering. Positional service providers, and service providers generally, who approach consumer engagement strategy in this way can develop deeper and more authentic relationships with consumers that result in reputational benefits and competitive advantage (Boardman et al., 2018). For resource and capability which is included in the category sustained competitive advantage, then Samana Resto Villa and Catering is required to continue can keep up and continue to do maintenance strategy in resources and capability. The resource-based approach holds considerable promise for exploring the role of strategic promotions in gaining and maintaining competitive advantages. Furthermore, this approach provides an important base for understanding the effective management of promotion, a critical focus of this work (Ireland et al., 2002).

As for the Resources strategy and Samana Resto Villa and Catering capabilities is already included in the sustained category competitive advantage, namely: Resto Villa and Catering design, Room Quality, online collaboration travel agent (OTA), Cooperation with offline travel agent, cooperation with services accommodation, cooperation with the object tourism that is around, Relationship with environment/surrounding community, Relationships with Visitors, Abilities/Skills marketing, Ability/Skill building and designing Resto Villa and Catering. In addition, the consumer's perception of value during consumption is based on how well the offerings they prioritize facilitate consumption goal achievement (Cho \& Lau, 1997). Its competitive advantage continuous is the ability of a company to creating a product that is on when competitors attempt to imitating it will always experience failure significantly. When companies implement strategies and competing firms do not on an ongoing basis apply it as well as other companies unable to imitate excellence the strategy then the company is said to have its competitive advantage continuous (Dalimunthe, 2017). A company is said has a competitive advantage when implementing a strategy, the competitor's value creation current potential or not apply at the same time. Likewise, when companies' others cannot duplicate the benefits of the strategy. To change potential resource to be its competitive advantage sustainable, it must contain the following four attributes: First, must valuable (Value), in the sense that it is exploiting opportunities to neutralize threats within Company environment. Second, it must unique or rare (rareness) in between current companies and competitors' potential. Third, you must not have imitated or cannot be imitate perfectly imitable. Fourth, nonsubstitutability, namely there is no substitute for strategic one equivalent for resources (Paryanti, 2015). The second main driver of profitability is sustainable competitive advantage (Hamilton \& Selen, 2003). 
Low cost strategies are not sustainable, as eventually the competitive advantage diminishes and the market becomes one of price minimisation with the less competitive operators failing (Sampurno, 2010). Think that when providing more value than the competitors, enterprise could obtain more customer perceived values, which can be deem as competitive advantage to develop market ability that is relative with sales growth measured by CPV (Y. Liu \& Sun, 2015). The VRIO framework is a too used to analyze internal company resources and the ability to know whether the company can become source of competitive advantage sustainable in his book Resource-Based Theory: Creating and Sustaining Competitive Advantage. VRIO is short for from Valuable, Rare, imitate to cost, and organized. VRIO can used to see comparative comparison regarding strengths and weaknesses conditions internal company (Marina et al., 2017). For identify which factors most importantly, even excellence competitive of an organization, can done by using VRIO framework (Wandrial, 2011). VRIO model this is what it is used for identify whether a resource certain of the company is strength or weakness. VRIO framework is compiled with a number inquiries about business activities company, which is about values (value), rarity (rarity), imitability (possibility of imitation), and organization (H.-W. Liu \& Yang, 2014).

Furthermore, strategic resources and capabilities must have four attributes referred to as VRIO, namely: Valuable (valuable). Source power and capability must have considered valuable to organization so allow for exploiting the opportunities that exist and neutralize that threat come; Rarity (rare). Resources and capabilities must be unique. Source power that only can be used by two or three organizations can classed resource ones rarely; Imitability. Resources and capabilities must also be difficult to imitated, imitated and even replaceable; Organization. Resources and capability itself will not provide an advantage for organization if that resource not well organized to catch that value owned these resources (Rothaermel, 2013). The relationship between IT and competitive advantage has been the academic focus of attention and debate issues. Although many researchers found that IT investments contribute to help firms gain competitive advantage (Chi \& Sun, 2015). While the strategy can have done in terms of capabilities are, service skills with care improve employee capabilities in serving visitors as well improve language skills by taking trainings, networking skills, this can be done by increasing the number of networks and cooperation so that it can create new networks and can increase the number of visitors.

Based on the description of the research results and discussion above, the suggestions that can be conveyed in this study are it was hoped that the Samana Resto Villa and Catering can make it happen strategy recommendations already formulated for development the effort of strategies alternatives that have been such as maximizing use of the internet as promotion and branding means, increase in the number of employees industrial background hospitality, include employees at workshop events, seminars or training regarding the hospitality industry, cooperate with parties travel and tour agents, as well increased use of technology, and expanding networking Resto Villa and Catering, next expected strategies alternatives that are not selected from the results of alternative strategies which the author has suggested, can be used as input strategy that can run for the future.

\section{CONCLUSION}

Based on the results of the analysis VRIO (Valuable, Rarity, Imitability and Organization) obtained from the results interviews with several informants, found there are 18 resources and existing capability at Samana Resto Villa and Catering can be detailed tangible resource competence as many as 8 and intangible resources amount to 6 while for capabilities are 4. Competence which belongs to the Samana Resto Villa and Catering more from the aspect of resources compared to its capabilities because resource competencies amounted to 14 and competencies are 4 . Based on 18 resource and capability included in a category that is rated highly need a new strategy like for resources owned by Samana Resto Villa and Catering has a strategy can be done, namely from source human power, this strategy is carried out by involving HR in workshop, seminar or event training on the hospitality industry as well as increasing the number of employees have competence in the industrial field hospitality, facility (Wi-Fi) strategy can be done by maximizing use of the internet as a means promotion of dissemination of information regarding Samana Resto Villa and Catering at once as a branding tool, location for attracts visitors not just locations strategic but needed also cooperation with parties travel and tour agents, because of the strategy this can be done as a means promotion and branding for Samana Resto Villa and Catering, the use of technology, can be done by making use of android to increase promotions and improve service by application android. 


\section{REFERENCES}

Ahmad, R. (2013). Kajian Atas Konsep "Keunggulan Kompetitif Berkelanjutan” Dari Nicole P. Hoffman Dan Pengembangannya. Jurnal Ekonomi Dan Bisnis, 23(3). https://www.ejournal.unair.ac.id/JEBA/article/download/4514/3035.

Alianto, H., \& Arlan, F. (2012). An Analysis Of Sales Information System and Competitive Advantage (Study Case of UD. Citra Helmet). CommIT (Communication and Information Technology) Journal, 6(2), 69-75. https://doi.org/10.21512/commit.v6i2.572.

Appiahene, P., Missah, Y. M., \& Najim, U. (2019). Evaluation of information technology impact on bank' s performance: The Ghanaian experience. International Journal of Engineering Business Management, 11,1-10. https://doi.org/10.1177/1847979019835337.

Asty, W. (2017). Strategi diferensiasi untuk menciptakan keunggulan bersaing di Savali Hotel Padang. Soshum Jurnal Sosial Dan Humaniora, 5(2), 153-162. https://ojs.pnb.ac.id/index.php/SOSHUM/article/view/324.

Barone, M. J., Norman, A. T., \& Miyazaki, A. D. (2007). Consumer response to retailer use of cause-related marketing: Is more fit better? Journal of Retailing, 83(4), 437-445. https://doi.org/10.1016/j.jretai.2007.03.006.

Blake, J., \& Kerr, D. (2019). Seniors Use of Social Media. Asia-Pacific Decision Science Institute International Conference (APDSI).

Boardman, D., Raciti, M. M., \& Lawley, M. (2018). Outperformed: how the envy reflex influences status seeking service consumers' engagement. Journal of Service Theory and Practice, 28(6), 752-773. https://doi.org/10.1108/JSTP-08-2018-0179.

Butarbutar, K., Tricahyono, D., \& Djatmiko, T. (2017). Analisis Perumusan Strategi Bersaing Telkomsel Regional Jawa Barat Menggunakan Konsep "Resource-Based View of The Firm" dengan Kerangka VRIO. Journal of Accounting and Business Studies, 1(2), 1-10. http://journal.ithb.ac.id/jabs/article/view/169.

Chi, J., \& Sun, L. (2015). IT and Competitive Advantage: A Study from Micro Perspective. Modern Economy, 6(3), 404-410. https://doi.org/10.4236/me.2015.63038.

Cho, V., \& Lau, C. (1997). An Integrative Framework for Customizations on Satisfaction: The Case of an Online Jewelry Business in China. Journal of Service Science and Management, 7(2). https://www.scirp.org/html/9-9201612_45532.html.

Dalimunthe, M. B. (2017). Keunggulan Bersaing Melalui Orientasi Pasar dan Inovasi produk. JKBM (Jurnal Konsep Bisnis Dan Manajemen), 3(2), 140-153. https://doi.org/10.31289/jkbm.v3i2.357.

Djokoto, J. G. (2021). Level of development, foreign direct investment and domestic investment in food manufacturing. F1000Research, 10, 72. https://doi.org/10.12688/f1000research.28681.2.

Hamilton, J., \& Selen, W. (2003). A Strategic Path to Competitive Advantage for On-line , Small- to-MediumSized Enterprises within the Service Sector. Journal of New Business Ideas and Trends, 1(1), 20-37. http://jnbit.org/upload/HamiltomSelen_1_1_2003.pdf.

Haryanto, A. T., Dewi, S. N., \& BRM Suryo Triono. (2019). Marketing and Competitive Advantages ( Study of Finance Companies in Wonogiri ). Jurnal Perilaku Dan Strategi Bisnis, 7(2), 115-123.

Ireland, R. D., Hitt;, M. A., \& Vaidyanath, D. (2002). Alliance Management as a Source of Competitive Advantage. Journal of Management, 28(3), 413-446. https://doi.org/10.1016/S01492063(02)00134-4.

Lenggogeni, L., \& Ferdinand, A. T. (2016). Faktor-Faktor Yang Mempengaruhi Keunggulan Bersaing Dalam Upaya Meningkatkan Keputusan Pembelian. Diponegoro Journal of Management, 5(3), 840-851. https://ejournal3.undip.ac.id/index.php/djom/article/view/14673

Liu, H.-W., \& Yang, L.-R. (2014). Influence of Marketing Strategy on NPD Performance: Role of Customer Perceived Value and Product Characteristics. Open Journal of Social Sciences, 2(3), 34-38. https://doi.org/10.4236/jss.2014.23007.

Liu, Y., \& Sun, Q. (2015). A Comparative Study of Competitive Brand Based on Customer-Perceived Value-Evidences from IAT. Open Journal of Social Sciences, 3(7), 275-282. https://doi.org/10.4236/jss.2015.37040.

Marina, S., Hanifah, H., \& Agusinta, L. (2017). Pemasaran Kerelasian Dan Keunggulan Bersaing Unit Bisnis Kargo Pt Garuda Indonesia Relationship Marketing and Competitive Advantage in Business Cargo Unit Pt Garuda Indonesia. Jurnal Manajemen Transportasi \& Logistik, 4(3), 267-276. https://doi.org/10.25292/j.mtl.v4i3.166.

Masri, H. A., \& Jaaron, A. A. M. (2017). Assessing green human resources management practices in Palestinian manufacturing context: An empirical study. Journal of Cleaner Production, 143, 474489. https://doi.org/10.1016/j.jclepro.2016.12.087.

Mucharreira, P. R., Antunes, M. G., Abranja, N., Justino, M. R. T., \& Quirós, J. T. (2019). The relevance of 
tourism in financial sustainability of hotels. European Research on Management and Business Economics, 25(3), 165-174. https://doi.org/10.1016/j.iedeen.2019.07.002.

Paryanti, R. (2015). Pengaruh Strategi Diferensiasi Terhadap Keunggulan Bersaing (Studi Pada Hotel Resty Menara Pekanbaru). Journal of Chemical Information and Modeling, 2(2), 1-13.

Rothaermel, F. T. (2013). Strategic Manajement: Concepts and Cases. The McGraw-Hill Companies.

Sampurno. (2010). Manajemen Strategi: Menciptakan Keunggulan Bersaing yang Berkelanjutan. Gadjah Mada University Press.

Shidqi, M. F., \& Tricahyono, D. (2017). Formulasi Strategi Hotel Rumah Tawa Dalam Rangka Meningkatkan Keunggulan Bersaing Melalui Pendekatan Resource-Based View. EProceedings of Management, $4(2)$, 1487-1493. https://openlibrarypublications.telkomuniversity.ac.id/index.php/management/article/view/35 02.

Song, W. (2012). Achieving Competitive Advantage through Innovation: The Case of the Shanghai Supermarke. Knowledge Management and Drivers of Innovation in Services Industries, 77-94. https://doi.org/10.4018/978-1-4666-0948-8.ch008.

Sugiyono. (2011). Metode Penelitian Kuantitatif, Kualitatif, dan R\&D. Alfabeta.

Töpfer, A., \& Brabänder, G. (2021). Personalisation of treatment pathways - analysis of chances and barriers by the implementation of digital technologies under the conditions of the German Health System. F1000Research, 10, 147. https://doi.org/10.12688/f1000research.29969.1.

Umar, H. (2002). Metodologi Penelitian Aplikasi dalam Pemasaran (2nd ed.). PT. Gramedia Pustaka Utama.

Wandrial, S. (2011). Analisis Internal Perusahaan (Strength \& Weakness), Menggunakan konsep 'Resource-Based View of the Firm' dengan Kerangka VRIO. Binus Business Review, 2(2), 627. https://doi.org/10.21512/bbr.v2i2.1457. 